\title{
Modernity and the Revival Thought, an Overview on Political Thought of Seyed Qutb
}

\author{
Hassan Hajizadehanari ${ }^{1}$, Reza Jalali ${ }^{2}$, Akbar Ashrafi' ${ }^{2}$, Ahmad Bakhshayesh Ardestani ${ }^{3}$, Seyed Mohammad Mehdi \\ Ghasemtabar $^{4}$ \\ ${ }^{1}$ Assistant Professor, Department of educational science, Farhangian University\& Department of political science, \\ Islamic Azad Central University, Tehran, Iran \\ ${ }^{2}$ Assistant Professor, Department of political science, Islamic Azad University Central Tehran Branch, Iran \\ ${ }^{3}$ Professor, Department of political science, Islamic Azad University Central Tehran Branch, Iran \\ ${ }^{4}$ Assistant Professor, Department of educational science, Farhangian University, Tehran, Iran \\ Correspondence: Hassan Hajizadehanari, Assistant Professor, Department of educational science, Farhangian \\ University\& Department of political science, Islamic Azad Central University, Tehran, Iran.
}

Received: August 8, 2016

doi:10.11114/ijsss.v4i10.1788
Accepted: August 23, 2016

Available online: September 27, 2016

URL: http://dx.doi.org/10.11114/ijsss.v4i10.1788

\begin{abstract}
Islamism is one of the most important trends in the twentieth century and the beginning of the third millennium. Although this trend has had various spectrums, they all have a common viewpoint in a few subjects and that is: modernity could not fulfill the promise of redemption and happiness of the man that had given its promise at the beginning of the age of enlightenment. Modernity is incompatible with many of the Islamic moral and value foundation and finally, for solving the problem of underdevelopment, westernization and so on "Rituals" of Islam should be restored. This article will investigate the thought of one of the Islamists, namely Seyed Qutb with this main question: "How much modernity which is one of the main components of the intellectual system of Seyed Qutb influence the formation of his political thought?" Additionally, it is also considered that the Islamists such as Seyed Qutb have faced to what contradictions in opposition and criticism of modernity. To investigate this question and the subject "hermeneutics Skinner" method is used in the study of political thought. Moreover, the discussions and the theory of "East Studying" are used for more precise and complete analysis of thought of Seyed.
\end{abstract}

Keywords: modernity, Islam, Seyed Qutb, establishment

\section{Introduction: A New Era and the Idea of Returning}

The coming of a modern era and the beginning of a new stage of life had vague and ambiguous messages to human. The modern man by passing through the traditional stage, put a step in a way that had a clear starting point, but it was not and is not obvious that it will end to what point. The steps that initially had more stability and certainty and aimed to discover uncharted areas by reinforcing scientific curiosity. Milan Kundera knows the beginning of new era when "Don Quixote left his home to explore the world" (Milani, 2001). The beginning of the discovery of the unknown areas and curiosity about closets that was already considered illegal and forbidden caused all aspects of human life including economic, political, social, religious and even artistic aspects to be changed extensively.

Brian Turner knew uninterrupted and continuous changes as the essential character of modernity. In his opinion "Modernism is actually an expression of how abilities, visions, concerns, anxieties and modern concerns originate from the heart of modern economic life. Considering the flagrant examples like the continuous and uninterrupted pressure of it to grow and advance, expansion of human requirements beyond the borders and local, national and moral areas, endless change and transformation of all of its values in the vortex of the global market and extensive destruction of all things, perhaps this is one of the most comprehensive definition of the new era (Turner, 1996). The emphasis of Turner regarding the modern society in which people are willing to remove all moral and religious borders and ignore the values that were already familiar to them to meet the economical and material demands is absolutely true and correct.

Modern man pays more attention to earth and whatever exists in it and focuses less on the celestial things. In the new thinking, events are not celestial and every things should occur on the earth because new thinking is incompatible with 
legend and myth and divine realm. The human's taking distance of holy sanctities also have roots and consequences. When human completely subdued to the nature, he had resorted to the God for freedom from fear and punishment by nature and by giving abundant sacrifices had quenched the wrath of the nature, even though this, human was disable in front of the nature. In a report of Jalal Al-e Ahmad about life and traditional human, the weakness and cowardice of human against the nature has been well displayed. He describes Orazan winter, a village near the Taleghan of Tehran in this way:

"Weather is very cold and five months of the year due to the snow and blizzard none of animals cannot come out from their nest. Cattle and sheep are maintained in barn which is a crypt plucked in the mountain to protect them from the cold and residents remain in the basement with a window to the arch or the top of the wall and a door to the hallway with an oven in its middle (Al-e Ahmad, 1997).

But when the man could harness the nature, he achieved so much pride so that he not only did not fear the nature and consequently, did not need to the mediation of Gods, but also he knew himself the God Almighty of the nature. He even did not need to otherworldly salvation since he could manage and harness the nature and he wanted to create the promised paradise on earth. He now wanted to remove his metaphysical rival to create a new thinking to overrule upon the earth based on it and thus, gradually went to war with religion and God. For this reason, Iris Murdoch says "the modern philosophy has an anti-metaphysics spirit. The character of anti-metaphysics can be summarized in this notification that may not have a deep structure (Smith, 2002).

"The challenge of the man with God in the modern era and the horrors that human has about the end of this fight despite the fact that humanism apparently hopes to his victory - caused some know one of the distinguishing features of the traditional and modern world in that how much the modern world gives unbounded and unlimitted freedom to human beings; it reduces his security and hope to the redemption to the same rate. It means that in the modern world, security is reduced in favor of freedom. But the tool of the war with God is the replacement of self-constructed wisdom instead of revelation and religious dependent wisdom. Human after taking gradual distance from God puts God's commands and orders away and tries to establish a new order which is independent of the revelation. In this regard, Marx says: "Whatever is hard and firm, is disappeared and vanished, and whatever is holy, becomes worldly and finally, human beings are forced to face with actual situation of life and their relations with their fellow human beings with patience and wisdom" (Berman, 2007).

The self-constructed modern wisdom by depriving itself of a divine source puts epistemic support umbrella away and tries to understand and change the world solely. In this new equation, the man tries to see more and is sure that after seeing can understand, but the knowledge of traditional human about the world is more than the something that was understood and heard from the metaphysic. He was a listener more than the viewer. In fact, the source of the knowledge for human was more cognitive that was given to him from the outside (Feyzollahi). Henry Corbin explains such cognition as: "Listening means depositing the string to the other. No matter the other to be the Holy Spirit, angel and old man with stories of exemplary lessons and worldview. In the Iranian thought, thinking means speaking at the heart and answer to the call that does not stop calling us" (Shayegan, 1992).

But gradually, after several centuries, modern man began to stop himself in the West to rethink about the realization rate of dreams in his enlightenment era. He was originally going to build heaven on the earth to be needless of the heaven of God, but not only had failed to fulfill it, but new life had new risks that caused some are looking back to pre-modern lost paradise and others think to past this stage and some merely began to formulate this stage of despair and fear. Schools such as postmodernism, romanticism, nihilism and thinkers like Freud, Marx, Marcuse, Nietzsche, etc., represent the nonproduction of Heaven on the earth by self-constructed modern wisdom. Henry Corbin teased to the claims of modern wisdom in establishing paradise on earth writes: "In front of the philosophy that laughs to the man's beard and even does not see that the man is unanswered to his chronic and immediate issues, against the philosophers from Descartes to Kant and from Hegel to Marx that thought to rescue us by keeping human to his nature, by relying him on the wisdom and determination doomed to failure, it is true in tune with one of the prophets of time to declare that human wisdom is not his existential reason. Not that I think therefore I am, the truth is that I was thought therefore, I am "(Shayeghan, 1992).

In the modern era, man's relationship with God which gradually from fear and love relationship became indomitable fighting relationship had very deep and terrible consequences for him. The man who by modern consciousness and self-constructed wisdom could overcome the nature to the great extent, now, without emotional support and through a machine and nearly meaningless life could achieve to every material things that he wanted and whatever he could not get, he was sure that can achieve once, but the man was separated from his origin and was unconscious to his destination. All these fears cause many to doubt the ideals of modernism and express their discontent. The examples of this dissatisfactions previously mentioned. But this dissatisfactions in the East, especially in Islamic societies were 
doubled. They were engaged in a process which although they were not its originator, they could not be immune from its devastating consequences. However, in the not too distant past and in the present time, still many in the East consider the West as a full-fledged model, but on the contrary, there are other people that in addition to the collapse of their past sanctities and values by new thinking, do not like objective outcomes of this new life. The thought of our intended thinker - Seyed Qutb - is completely dependent into this space and this new world. In our opinion, at least one aspect of the thought of Seyed Qutb or half of it is clearly a response or reaction to the West's assault on the principles of Islamic values. His response to these attacks is manifested in a general idea that we call it "the idea of returning" which will be discussed in the following.

East in West's assault and the reaction of intellectuals

When modern civilization and its discontents enter to the East, becomes more complicated. Orientals in addition to being forced to react the advantages and disadvantages of modernity, also need to consider that it is a new phenomenon and other uninvited guest, especially in Islamic societies in which people believe the glorious and golden past, the acceptance of components of modern civilization is associated with more doubt, but the influx of modern values to the eastern countries faced us with a wide range of reactions from full acceptance to selective choice as well as the total rejection of West. Seyed Qutb is one of the thinkers that knows west a full-fledged demon for various reasons. In his view, the current status of west is nothing except the success of devil and because of this evil spirit of the West, he believes that the achievements of modern civilization not only are not prosperous and emancipatory, but he votes to the human bondage in the context of the civilization. Therefore, he extends the concept of pre-Islamic society for analyzing the modern society and showing its defects (Safi, 2000).

Seyed Qutb is upset, sad and angry because of several issues. According to him the West civilization lacks any spirituality and spiritual elegance. A civilization that despite the remarkable and captivating advances failed to give suitable response to the emotional and spiritual needs of people. Seyed likens the civilization of West to a bird that has only one wing: today's materialistic civilization stands like a bird with one wing which looks for the crop, while its other wing after healing again is broken. Whatever it advances in the material industry on the other hand takes distance from the human spirituality and sinks in such anxiety and confusion, and fatal ethnic and sensual heart patients that wonders intellectuals... because they do not come back to the doctrine of God which is the only treatment and medication (Seyed Qutb, 1982).

From the viewpoint of Seyed Qutb, people's negligence has caused the modern tyrant to be arisen and contrary to what is thought that the modernity is as savior of mankind and services him, conversely, it plunged him into the terrible abyss. Western technical achievements are not only relaxing, but also a great tragedy. A tragedy that by scoffing all moral values and permitting the majority of illegal and banned things reduced the man from the human dignity.

This new civilization reflects a kind of rebellion against the creator of the world. The new man is a man who has rejected the sovereignty of God and by disobedience wants to conflict with God. This is hard and unacceptable for a Muslim. Seyed also is aware of such transgression and rebellion. He believes that the justifiability of everything in Europe is because of that the European man does all these works to say the church to take its God, religion and the man that in its opinion God breathed his spirit into it and gets away from their real life (Seyed Qutb, 1997).

Removal of creator God led to the emergence of new gods in the West and finally ... a man who considered a god other than Allah; considered the wealth, whim, material, land, race, and lawmakers as God to arrogate the special right of God by them and thus, took over the divinity right of Allah. Human being constructed and worshiped all these gods to flee and refuse from God and his worship (ibid).

Sunset of God in the West and sunrise of a cloud of man who knows himself master of the world, creates a major change and it is that humanism becomes an alternative for divine caliph position of human and human by advancing gets away from God and boasts his compositions to God and constantly emphasizes that I have made these instruments. Humanistic pride does not allow the man to admit that his compositions are derived from divine mercy.

When the cognition of Seyed about the West was formed in this way, he resorted to the logic of this or that. A movement that was formed among some Islamic scholars namely, the availability of selective choice from western civilization and its inhibition within the framework of Islamic tradition and laws, was not acceptable for Seyed. Because he believed that there is no link and equality between Islamic tradition and elements of modern civilization. For this reason, he completely negates the western civilization. But he says this religion [Islam] is a common announcement for the freedom of man on earth, freedom from slavery of servants and whims. This is a notification which means burning and destruction of human society [New] is to bring the kingdom of God on earth (Qutb, 1983). In fact, he believes that telling No God but Allah (Laa Elaaha Ella Allah) negates all the rituals of human and any discipline that its creator to be other than Allah, should be rejected and rejected. 
Political Thought of Seyed Qutb is formed and formulated between two elements. He as a devout Muslim who is aware of his golden past in the beginning of Islam, is present in front of assault and aggression of the norm.

Sayyid Qutb's thought on the one hand is emerged from opponent and alien and foreign invaders and on the other hand, from his religious training and Islamic beliefs. Therefore, his thoughts can be considered neither background-based nor text-based. It is here that we approach to the methodological foundations of Skinner. As Skinner believes: background reading considers the background as context meaning determinant and therefore, understanding the meaning of any text is subject to the understanding of the intellectual, social, religious, economic and political fields of that text, but the reading text method focuses on inherent autonomy of text as the only indispensable key for its meaning and puts any attempt to reconstruct the social context as futile attempts aside. However, Skinner by criticizing both methods proposes the methodological plan which is both field-based and text-based (Skinner, 1988).

Hisham Jeait about the nature of contact among different cultures and the result of this contact writes: contact among cultures always lead to the emergence of drama, drama of ontological and ethnic of human differences or existential and intellectual drama in life of a person. Surface contact creates a unfamiliar feeling, and deeper contacts contain the risk of losing personal nature, rupture of its integrity, the end of determination and mental-wounded challenge in relation to the values of oneself (Broujerdi, 1998).

When the contact of cultures took place between two completely different worlds, the mental challenges become doubled and the contact between modern culture and Islamic culture is as follows: The modern culture that one of its inherent complications is the elimination of past customs and habits is placed in contact with the culture that the past is its proud. Modernism so mercilessly destroys the old values with so attempts. In this regard, Marx says: after the birth of mechanization and modern industry, a foundation-destroyed flood started that in the severity and magnitude was like an avalanche and broke all moral and natural limits, age and sex, light and darkness and capitalism celebrated its victory and elsewhere, describes the nature of the modern era in contrast to the sanctities and former values: whatever to be firm was vanished, and whatever to be holy became worldly and finally, human beings are forced to encounter the actual situation of life and their relations with their fellow human beings with patience and wisdom (Berman, 2005).

Modernism is based on the transformation. The promise of the new civilization is that humans have to destroy everything in the interest of progress. The stability of objects, phenomena and moral elements is impossible.

The only constant and indisputable principle is transformation. Thus, in a modern definition, the successful individual is a man that is able to change himself and not committed to anything and unsuccessful human is a man that cannot abandon his old values.

For this reason, Rousseau surprised his contemporaries by announcing that the European community is standing on the threshold of the most explosive throes of revolution. He experienced everyday life in the community-especially in Paris, its capital - as a hurricane, social tornado (Berman, 2005).

In this context, the main enemy is the modern lifestyle and the ancient traditions of the past. Modernity more than everything intends to completely erase old memories or looks them as antiques that are only worth keeping in museums. Modern view does not let the traditional relations influence on the daily life flow. In this respect, traditional human committed to the moral values is as a disease that should be treated or removed and to eliminate such humans, modernity basically destroys their ground and roots. From the perspective of Futurist that is one of the most important cultural movements of modern, tradition is the cause of all misery.

However, how much the western and modern civilization to be destructive and totalitarian, the traditional human is equally resistant as well and tries to maintain these traditions and this is where the conflict begins between tradition and modernity. On the other hand, modernity tends to change everything to its color and on the other hand, tradition efforts to protect its memories and honors.

Dariush Shayegan in the Asia book in front of west quotes an anecdote that demonstrates the lack of compromise between tradition and modernity (Shayegan, 2009). A confrontation exists between modern culture and Islamic culture and these conflicts.

The western civilization wants Muslims abandon their ancient values and enter to the main route of history namely modernization which is difficult for Muslims. Traditionalists in Islamic East were unhappy about such circumstances. Meanwhile, Seyed Qutb, as a decided Islamist is unhappy and angry about such infestation. In his view west is as a stranger that by entering into the privacy of Muslims wants to teach them religious. West is so shameless that should be careful about it and try to remove it. Seyed Qutb's thought is largely a reaction to the penetration of the western civilization to Egypt and other Muslim societies. 


\section{Knowing East in Service to the Survival of the Modern West}

As an alternative, the modern west in addition to the ontological conflicts, in the field of epistemology also threatens and humiliates Islam as a religion and creates another ignoble to achieve its interests. The other creation is not generally humanitarian and based on the good faith. Modern West to justify itself and to show non-modern hells need to its controversial example to create an East which is generally degraded and is different from its nature (Said, 2004).

In the meantime, the most important opposition that is done between tradition and modernity in the global arena is the confrontation between the West and East world, especially Muslim. The Western world and studying East introduces Muslims as a symbol of darkness, ignorance and barbarism and this viewpoint allow them to attack to Islamic world in any way; either by military attack or by cultural and intellectual invasion to the sanctities of Muslims. Orientalism humiliates Islam and considers it as backward which needs to be guided. From the perspective of the majority of orientalists, Islam is basically an opposite and hate-provoking phenomenon.

Edward Said in explaining this event between West and Islam believes that the identity formation process and its maintenance in every culture entails the existence of another different and competing twin. He expresses that in west representation process, orientalism is made as a twin for the West. Dichotomous vocabularies (opposite) of orientalism includes East versus West, despotism versus democracy, cruelty against fair dealing, irrationality versus wisdom, and cunning against trust. With absolute fixing of meaning of East, orientalism as a Foucaultian discourse gets function from power and domination and this is what can stimulate all Muslims to resist against the West.

The expansion of secularism along with the emergence of the discourse of "colonialism" in the late seventeenth and eighteenth centuries strengthened dual mental mold of West. The emergence of terms like "civilization" in the middle of the eighteenth century, the "West" in the middle of the nineteenth century, makes equivalent and necessary the placing "barbarians" and "Orientals" as "others". Thus, the dichotomy of civilization- barbarism and West-East was simply replaced by the dichotomy of Christianity - Islam which was common during the middle Ages (Broujerdi, 1998).

The Orientalism is based on that the Western people are creative and more civilized with better race and Orientals on the contrary, have more ignoble and wild race that need to be cared. Orientalism with this fundamental distinction between these two worlds introduces itself as the bright side of life and the other as its dark side. In fact, the West in this way relates the inferior position the East and simultaneously, it is in the service of shaping the superior position for West. Sardar says that such a dual forecasting for West is the live force of identification to oneself (Sardar, 2000). Shariati about such a view sarcastically wrote "even Ernest Renan who is humanitarian also said that the West is employer race and the East is the worker race and this is why the nature increases the worker race and decreases the employer race. Siegfried said that western people have industrial, administrative and civilization-maker brain, but eastern have sensational and average brain which is unable to think and conclude.

In the twentieth century, Orientalism focused particularly on the area of Islam. In fact, Islam in many Orientalism researches was introduced as another ignoble of East. Apart from westernization that is one of the reactions to the Orientalism studies in the twentieth century, Orientalism focused particularly on the areas of Islam- and during that westernization person accepts all attitude of Orientalism and he admits to his ignobility and confirms- the use of Orientalism or discourse in reverse is another reaction (Adibzadeh, 2008). As Sadegh Jalalol Azm says duality one/ other is not in the siege of a particular culture and discourse (e.g., American discourse about the East, Islam and Iran), but a bilateral global trend is for reciprocal representation of East and West that can be reversed as Orientalism (Alazm, 1988).

In this model, discursive subject begins to create an anti-discourse namely, conflicts with Orientalism. Perhaps the most important one that points to the need to create an anti-narration against West narration is Frantz Fanon who believes that as long as in service consciousness not to be eliminated freedom cannot be gained. Terminating this ignobility situation requires to violate the ceremony and create an anti-narration to specify the boundaries of the colonial and colonizer again (Broujerdi, 1998).

Seyed Qutb is also among scholars that not only was not westernization-because the hypothesis of the paper is that a considerable part of the idea of Islamic thinkers in the nineteenth and twentieth centuries is a response to the devastating invasion of the West to the Islamic world in the various fields of political, economic, cultural, intellectual and so on- but also by providing a reverse discourse, scoffed all things that the West makes its own pride, and considered them worthless.

However, in many writings of Seyed Qutb, numerous examples can be seen about humiliation of West, but here we refer only to one of them which is his idea about America when he had traveled to America from the Egyptian Ministry of Education to study the American educational system in America. He about America in a letter to Mohammad Jabar wrote America is the biggest lie that the world has ever heard. Life here is based on pleasure and pragmatism and moral 
and humanistic values are ignored and all these values are ridiculous for them (Outb, 1987).

One of the most basic intellectual concepts of Seyed Qutb is meaningful in this context. He creates an important anti-concept in front of all assumptions of Orientalism that introduce all Islamic societies backward, irrational and so on. While many religious thinkers have confessed to the material development of modern civilization of the West - and however, they do not prescribe the Western version to Islamic societies and put doubt mark in front of linear model of development. Sayyid Qutb not only does not know Western version effective for the Islamic world but also does not believe the development of the West. The concept of ignoble society gets meaning here.

Seyed Qutb first in several places provides definitions of ignoble society such as "all places where conflict with the idea of a true Muslim and ignore the commands of Islam are warfare places" (Seyed Qutb, 1983) and elsewhere writes we never excommunicate people; we say, the people in terms of ignorance of the Islam faith, are similar to the ignoble society in the beginning state of prophet's invitation (Seyed Qutb, 1990). In another part of the book Worlds "Ma'alem", Seyed Qutb knows the lack of God's slavery as a sign of ignorance of a society. The ignoble society is a society that does not obey God completely (Seyed Qutb, 1983). In fact, from the perspective of Gutb, in a society in which the words of people take precedence to the words of God, it is an ignoble community. More precise is that Seyed Qutb never accepts the slogan of that the word of people is the word of God.

Seyed Qutb, after expressing his purpose and meaning of ignoble community begins to create a similarity between the age of ignorance before Islam and the current modern societies of West and with this simulation attempts to humiliate the West. He in the introduction of the book of Fee Zallalel Quran writes Islam took the lead when the earth was full of corruption and life had been ruined. The government was full of stink and the humanity had felt bottleneck by living under the burden of the stinking governments. This phenomenon in purity and beauty, being great and high, clarity and simplicity, establishment and conducting, and consistency and conformity was in a way that humanity did not never reach it, unless when God wanted it for him and realized it in his life by referring to the manner and guidance of the Qur'an. Then, the disaster of modernity happened and Islam was ousted from the leadership when ignorance had strengthened, this time in various face like material intellectual face that today's humanity stares at it (Seyed Qutb, 1982).

Seyed Qutb redefines the concepts in the form of a reverse discourse, concepts that previously were known in Western definition. He on one hand in the first stage with definition of ignorant society found the cases in all countries and among all the western states. In the next stage, he redefines civilized society as well. In his view, civilized society is not where the material progress to be the first priority with giving limitless freedom to individuals; but civilized society is a society that

- Where God alone is the judge and this is the only problem in which human truly becomes free from servitude to other people entirely.

- Society is a society based on belief and religion and thought and way of life, and that all of God is issued. But if a society based on race, color, ethnicity and geographic area are gathered, is not civilized.

- Community in that society is based on belief and religion and thought and lifestyle and all of these matters are issued by God. But if a society to be based on race, color, ethnicity and geographic area, it is not civilized.

- Where the humanity of man has had the highest value. Human values and ethics it is established.

- Humanistic values and ethics are established in that.

- The basis of community is family and the family to be based on specialty of couples in practice; This means that men and women do their own work, but when a society is built on the basis of free sex interests, when a woman's duty is seduction and sedition not human development which is her fundamental duty, such society is not civilized and has not abided the principles of civilization.

- In general, a society is civilized in which human, in an appropriate manner, does his duty as Divine caliph (Qutb, 1983).

Thus, Seyed Qutb by exchanging and replacing the civilization criteria and ignorance barbarism creates a new semantic structure that in framework of this structure west is declined from peak to perigee. Seyed Qutb by generalizing the ignorance of modern Western countries to the other Islamic and East countries that have incurred from westernization are providing solutions.

Return: antidote of latent Nihilism in modernity

The Seyed Qutb's thought has been shaped as the algebra of environment and temporal demand, but this algebra and demand only shape half of the intellectual set and system and the thought of Qutb was the other half. When he reaches the stage of presenting alternative to the West civilization and introducing a strategy to save humanity, his subjective 
assumptions and Islamic beliefs come to his aid.

These beliefs are manifested in the form of an idea and a strategy. The idea is "return" and solution is "the formation of an Islamic government". The idea of return and resuscitation is emanated since a disaster in the name of modern civilization of West is occurred. Among the occurrence of this disaster that is in conflict with the belief system of the Muslims, seeking identity is one of the main concerns of each Muslim. Muslims, mainly due to having glorious past, cannot easily raise the surrender flag against a new new-comer opponent.

At another level, in the West, in the words of Nietzsche, humans in response to the chaos of modern life show two types of reaction: trying to live and casting himself into the missing paradise (Berman, 2009). In fact, returning to the past and being satisfied with the ideals of the ancient world are not only for Muslims, but in the West one of the defense mechanisms of the complainant of modernity is insisting on past glory and emphasizing on that the new life removes the sweetness of old life.

In this context, complainant man in his inside thinks about his dreams that he or others had in the past; imagines the past life heavenly and new life purgatory. The myths and past memories become nostalgic for her.

But the important point is that returning to the past is not the main and dominant idea in the West in answer to the problems of modernity. Most of Western thinkers in addition to verifying that the modern life creates many of worries and anxieties of modern man, but they do not consider "return" as a solution.

But this situation is different for the world of Islam. Perhaps because modernity is created by the West. Muslims earlier and with less uncertainty return to the past in front of risks of modern life. Therefore, if traditionalism not to be dominant among intellectuals in the Muslim world, at least it is one of the main side -beside the other two sides of modernity and modernization (westernization)- of thinking in the Islamic world.

Seyed Qutb is also among the scholars who wish to return. The degree of rejection of modern civilization and confirming the past indicate his trend. As already mentioned, a thinking aspect of Qutb is responding to the risks of modern life, but when he enters to the stage of providing alternative, suggests Islam particularly, the Islam of initial periods.

This suggestion is emanated from his traditional religious education in childhood in a way that he had memorized all of Quran until 10 years old and his participation in political meetings that were held in his home and some of his personal life experiences caused Islam in his eyes to be the most comprehensive and complete religion in response to the human needs all of the times and therefore, he had found anti-British mood. In addition, religious education and precipitation of the idea of Seyed Qutb from childhood that the Islam is for all of the era and ages, his close encounter with modern civilization - especially during his trip to the United States- caused he found that how new civilization ridicules his religious myths and values and how it efforts to destroy and undermine the aspirations of this religion.

Seyed Qutb's intellectual project is based on nativism, past-oriented and providing an Islamic alternative to the West civilization which is also due to his childhood upbringing, his familiarity with the Quran and viewing the West feud with his religious myth. Seyed Qutb in this past orientation wanted to rescue Muslims from enthusiasm for the West (Westernization) and with renaissance of memories of hero and myths and values of the past tried the Muslims to feel proud of their past and get rid of aggressive indoctrinations of Orientalism, because he, Fanon, Aimé Sezer, Shariati and others believed that the most catastrophic situation is when Muslims are influenced by the West to doubt their past and consider themselves baseness. The existence of spiritual gaps and undermining ethical values in the West made Seyed and others who had and have "return" thought more determined, but past orientation of Qutb completely devoted to his own and here it becomes clear that any similar conditions can create intellectual closeness, but any two thoughts is not similar to each other and this individuality is expressed more in the intellectual world.

The return idea of Seyed Qutb is almost uncritical praise of the past. For him, whatever existed in the past is an absolute truth, whereas, for example, for Shariati full return to the past is impossible and dangerous. He says if I go back to my own race, I suffer from racism and fascism and ethnic - racial ignorance and this is a reactionary return. I do not want to say that art is only for Iranians, but I want to say the history has shown that I am an artist and made artists. For this reason, he expresses his intention of return in this way that if you have heard I rely on religion or Islam, my reliance on a reformed and revised Islam is consciously and based on an Islamic Renaissance Movement..... Returning to the Islamic culture and ideology and Islam, not as a tradition, heredity, and existing system or belief in society, but Islam as an ideology or a faith that apprised and created that miracle in the community.

This return is completely different from the intended return of Seyed Qutb who wants a total and complete return and his return is not a modified return. He wants the Islamic law and sharia to be implemented in verbatim form, while Shariati sees return only as an ideological return. Therefore, he instead of using a reformed Islam and crossing from crisis, looking back to the return to the lost paradise of early days of Islam. For this reason, he in the introduction of the 
Fee Zallal book writes "Following a period of living in the shadow of the Qur'an, I reached this strong belief that all of improvements on earth, comfort, peace or reconciliation, and compromise with the laws of the universe for human are possible in returning to Allah and this returning in the shadow of the Qur'an is a unique perspective and way (Seyed Qutb, 1982).

\section{The Establishment of Islamic Rule: The only Way to Save}

But the thought of Seyed Qutb is not just stopped in the general idea of returning. He reaches this general idea to the realization and objectivity phase in his thought. Returning to the past from the perspective of this Egyptian thinker is not impossible and inaccessible, but it should be reached to the result in three stages. For this purpose, the final piece of his thought is formed with three elements of anger, effort and finally, forming an Islamic government that is law enforcement.

Seyed Qutb in an article entitled "Schools of Lelsakhat" in 1946 wrote "If things were entrusted to me, I will build so many schools to teach only one thing and that is the dissatisfaction with the status quo and its ugly manifestations that have been dominant on all aspects of life of this generation (Seyed Qutb, 1993).

The anger is not a vulgar anger and based on self-love, but it is a holy anger that can stand up against the cultural and value invasion of West and can pave the way of returning. For this reason, anger expression will be meaningful in conceptual form of effort (jihad) that is one of the main pillars of Seyed Qutb's thinking. In his view, effort (jihad) refers to the sacrifice in the way of right to restore past greatness and glory by the end of death and life (Qutb, 1969).

He elsewhere writes "there is not any solution to save and rescue humanity from the mass of current problems and to maintain him by maintaining humanistic nature, except in Islamic thought, Islamic way and Islamic and social life. Accordingly, we believe that the Islamic society revolt is inevitable, natural and innate necessity (Qutb, 1997). Seyed Qutb by citing various verses of the Qur'an concludes that there are only two ways for human life and the third way cannot be imagined (Sheykh Ahmad, 1983).

But the anger, effort (jihad) and movement has a central point and final favorable. Islamic Jihad from the perspective of Qutb should be led to the formation of a divine government because divine system is the best in its own type because it is legislated by God and never and at any time religion of God's servant would not be like the religion of God.

Here, Seyed Qutb tries to destroy and weaken one of the main points that the human rebel against his own God. The modern era is the era of secular states in which the humanitarian command and law regulates the social relationships of human beings and this is not favorable for Islamism such as Seyed Qutb. Modern man by putting aside the religious orders begin to establish political systems. Now, to overcome this evil - secular governments - and to fight basically with modern ignorance and release humanity from confusion, religious state should be established. The most prominent criterion for being an Islamic government is the implementation of the holy law. Seyed Qutb says that any government in any form or title that the Islamic orders are implemented in it is the Islamic government and any government in which this law is not applicable, is not accepted by Islam even if by having Islamic title (Qutb, 1974).

Such a government is able to meet all human needs and most importantly, because the main issue of modern eras is ignorance, this government as in the early days of Islam could eradicate ignorance, this time is also the only power that can destroy modern ignorance. The desire to establish an Islamic state, more than anything else, makes evident the individuality and mentality effect on the formation of the ideas.

Seyed Qutb here takes even distance from his colleagues in Muslim Brotherhood (Akhavanol Moslemin). He unlike most members of the Muslim Brotherhood (Akhavanol Moslemin) and especially Hassan al-Banna - founder of the party - that considers education and cultural affairs as a way to escape from the dominion of the West civilization, believed that it is possible only through Islamic government. In fact, although the solution of Seyed Qutb is similar to that of Hassan al-Banna, it is not limited to Islamic education and it calls for the establishment of an Islamic government.

At the beginning, Muslim Brotherhood members particularly Hassan al-Banna believed that with the provision of an Islamic education and encouragement of people to return to Islamic behavior, can vaccinate Muslims in front of the Westernization disease. Therefore, invitation and promotion for religion was their most important assignment. Various branches that the Muslim Brotherhood members had established even outside the borders of Egypt in countries such as Palestine and Jordan and Syria, all were for the education and raising religious awareness of Muslims. A reference to a number of measures of the Muslim Brotherhood, - in the leadership period of Hassan al-Banna - displays his difference with Seyed Qutb in solution presenting stage.

The Muslim Brotherhood established the first Islamic girls' school in the Ismailiye with the name of Amahatol Momenin School. On one hand, in Cairo, Hassan al-Banna in addition to following up the major goals of population, continued his educational and propaganda activities in seven sectors that one of the most important of them is trying to 
revive holidays and Islamic historical days by forming the speeches and celebrations (Haj Seyed Javadi, 1979). On the other hand, making various spaces Islamic was the other objective of the Muslim Brothers.

The fifth chapter of demotic public law of population in different matters was that Article 63: adjustment and establishment of the Islamic atmosphere in factories, companies, and unions. Article 66: creating Islamic atmosphere in the agricultural environment and publication of Islamic education among them. Article 69: the family sector to study the family issues and to guide families to Islamization. Article 70: compilation and publication of Islamic education in the student-based environments to create Islamic atmospheres at universities and colleges (ibid).

According to the Seyed Qutb the only education discussion to counter the West's destructive civilization was childish and inadequate. In his view, if the general structure of a state not to be Islamic, any action and movement within the framework of Islamic education will be futile.

Of course, the different experience of two prominent leader of Muslim Brotherhood namely, Hassan al-Banna and the Seyed Qutb cannot be neglected. Seyed Qutb had experienced countless issues without Hassan al-Banna. Seyed Qutb knew the testimony of Hassan al-Banna in 1949 by secular government of King Farouk.

Moreover, Seyed Qutb have had a lot of cooperation to fulfill the revolutionary coup of 1952 led by Gamal Abdol Nasser, but Nasser after victory with an customary idea and not necessarily religious - Pan-Arabism - was only looking for the leadership in the Arab world and did not pay too much attention to the demands of Islamists and particularly, the implementation of religious orders. For this reason, secular government of Gamal Abdel Nasser became the continuation of larger entity of West for Seyed Qutb and this led to the necessity of creating a political - religious revolution in Egypt for Seyed Qutb.

All these cases caused Seyed Qutb to conclude that the treatment of humanity pain especially Muslims, is not something except the formation of a religious government. He took over the leaders of Muslim Brotherhood's population to achieve this goal and by its re-organization, the ideal of an Islamic government formation became the main ideal of the Muslim Brothers and he wrote his most important book, Ma'âlim Fe Tarighe and these were hidden from the secular government of Gamal Nasser. This caused Seyed Qutb to be tried in 1966 in a military court on charge of writing Ma'ālim book, trying to overthrow Nasser and leadership of an illegal organization of Brotherhood and eventually, this trial led to the execution of one of the greatest Islamic thinkers of the last century. Today, after the execution of two main intellectual leadership of Muslim Brotherhood while at the beginning of the Third Millennium the secular government of Hosni Mubarak has been dropped, Muslim Brotherhood population as the most organized Egyptian political establishment is in a position that can very seriously think about the realization of Seyed Qutb's dream while its main opponent had been failed.

The study of Seyed Qutb and his ideas in this space with respect to these components is important since many movements in Egypt and even in Muslim world are inspired by him and in terms of impact on Islamic movements, is one of the most prominent contemporary thinkers. Today, many Islamic organizations, groups and movements refer to the ideas of Seyed Qutb for opposing the westernized ruler of Islamic communities as well as providing an alternative for the tomorrows after the fall of these rulers and are inspired by him. This authority stems largely from the point that Seyed Qutb in addition to criticizing the Western lifestyle and its infiltration to Islamic communities, has a plan for tomorrow and also emphasizes on the Islamic state establishment. In fact, he is one of the few Muslim thinkers that explicitly acknowledge the necessity of forming an Islamic state and this has made him respectable with an exalted position in view of Iranian scholars and especially opponents of the Pahlavi regime.

In the context of the necessity of Islamic state establishment many approaches can be observed between Seyed Qutb and those like Seyed Mojtaba Navab Safavi and Imam Khomeini. Both Nawab and Imam Khomeini believed that the problems of Islamic societies and Muslims are only solved by establishing an Islamic state. For example, the commitment and the sanctity for legal principles and emphasis on the efficiency of Islam religion to manage every aspect of society is the most important theoretical proposition of thought of Nawab Safavi. In his view, like Seyed Qutb, Islam is a comprehensive religion that encompasses all dimensions of human life which has program for all personal, social and political aspects of human life. Nawab knows the execution of Islamic order as a way to save Iranian society from the problems and insists that if Islamic laws are implemented and the environment of Iran become excellent from beginning to the end (Nawab Safavi, Bita).

\section{Later: Puzzles of Seyed Qutb}

A review of the political and social areas of idea formation of Seyed Qutb and also the look at and focus on inherent concerns of an individual such as Seyed Qutb, makes it clear that the generality of invasions of West - with various ways - to the totality of Islamic civilization, strengthens the existing resistance veins among Islamists and fertilizes these veins completely. Therefore, the reactive nature of Seyed Qutb's thought is a point that should not be forgotten. 
This reaction is mostly in front of claims of orientalism and politicians related to these studies that by praising West and humiliation of Islam created a sense of resistance among people such as Seyed Qutb.

But after the formation of the thought, the important matters are the survival and consolidation and problem solution. If according to this article, assume that the Western civilization and its challenges, especially in contrast to Islam, is one of the main factors in shaping the thought of Seyed Qutb thus, those who are intellectually close to the thought of this Egyptian thinker should be able to response to those contradictions and paradoxes that Seyed Qutb was faced with them and failed to have proper and clear position against them.

The biggest dilemma of Seyed Qutb was that he did not specify his task with acceptance or rejection of Western technology properly. Today, plane, train, car, internet, various telecommunication networks and so on are the inseparable part of human life and these are souvenir of abroad, even intellectuals and writers who are in the spectrum of traditionalists do not have an avoidance of the use of modern tools: all lectures are done through the microphone; books are printed with modern printers, papers and writings are sent through the mail easily to other people anywhere and thousands of other complicated and simple technologies that have been used by critics of modernity.

Now, with these conditions, whether the opposition to the West civilization can spread to the opposition with these areas? Whether the idea of Islamists such as Seyed Qutb like Seyed Gamal is that the West's technology should be grabbed but it should be emptied of modern ideas and Islamic culture should be injected to the Western technology? This means that the West should be emptied of its content and local content should be given to it. In this case, is there any guarantee that the use of modern technology does not lead to the adoption of modern culture? Is it possible to stand behind the mic and spoke in rejecting West civilization?

Whether the return to tradition refers to the worship of originality and negation of the entire civilization of the West in all its aspects? Whether it means that a fortified and impermeable wall should be built in our intellectual and ideological boundaries against the Western mark and brand? Whether while the West causing the formation of Islamist thought, an Islamist can deny its base? These questions and any other questions all are problems that Islamists such as Seyed Qutb should find appropriate response to them.

\section{References}

......... (1997). Disaster of civilization and mission of Islam, Trans: Kermani, A.H., Tehran: Mashale Daneshjo (Torch of student) Press. (1969). What do we say? Trans: Khosro Shahi, H., Qom: Migration Press.

........... (1974). Social Justice in Islam. Trans: Gerami, M.A., and Khosro Shahi, S.H., Qom: Publications of Resalat Institute (1990). Why executed me? Trans: Arbabi, M., Saravan: Valid Publications.

............ (1983). Ma'alem Fe Tarighe, Beirut: Darolsharq.

Adibzadeh, M. (2008). Dialectics of the representation of the West in Iranian symbolic world, Akhtaran.

Al - Azam, S. J. (1980). " Orientalism and Orientalism in Reverse", Khamsin, NO.8.

Al-Ahmad, J. (1997). Orazan, Tehran: Majid publications.

Bergner, J. (2004). Literary criticism, Trans: Soujodi, F., Tehran: Ghatreh.

Berman, M. (2007). Experience of modernity, Trans: Farhadpour, M., Tehran: Publication of Tarhe No new Plan.

Boroujerdi, M. (1998). Western and Iranian intellectuals, Trans: Shirazi, J., Tehran: Publishing and Research of Frouzan Rouz.

Bryan, S.T. (1996). orientalhsm, postmodernism \& globalism, London: Routledge.

Haj, S. J. K. (2006). Egyptian Muslim Brotherhood in history exam, from Hasan al-Banna to Seyed Qutb, Tehran: Misagh Publication.

Hamdeh, A. (1987). Seyed Qutb Menanl Qariyateh ellal Mansheghah, Cairo: Dar Sinai.

Imam Khomeini (2002). Sahifa Nour, Collection of guideline of Imam Khomeini (RA), 2, Tehran: Publication of Shares of Ministry of Islamic Guidance.

Milani, A. (2001). Modernity and anti-modernity in Iran, Tehran: Publication of Akhtar.

Nawab Safavi, S.M. (Bita). Community and Islamic government, Bija

Qutb, S. (2002). Fe Zallalel Quran, Trans: Abedi, M.A., Tehran: Revolutionary publishing center. 
Said, E. (2004). Orientalism, Trans: Govahi, A.R., Tehran, Islamic Culture Publications Office.

Sardar, Z. (2010). Orientalism, Trans: Ghasemi, M.A., Tehran: Center for Social and Cultural Studies.

Shayegan, D. (1992). Horizons of spiritual thinking in Islamic Iran, Trans: Parham, B., Tehran: Publications of Aghah. Shariati, A. (Bita). Self-return, returning to which oneself?, Tehran: Office of development and publishment the collected works of Dr. Ali Shariati.

Rasoolinejad, A.A. (2000). Seyed Qutb and his lyrics, Tehran: Ehsan publication.

Shayegan, D. (2009). Asia against the West, Tehran: Amir Kabir Publications.

Sheikh, A. M. (2006). "Seyed Qutb and contemporary Islamism ", Political Science Quarterly, 33, Qom: University of Baqerol Olum

Skinner, Q. (1988). Meaning and context, edit by james tully, new jersey: princton university press.

Smith, H. (2002). "Defense of the perennial philosophy in the philosophy of seyyed Hossein nasr", The Library of Living philosophers.

Zargarinejad, G. H. (2008). Rasa'il of constitution, Constitution according to proponents and opponents, 1, Tehran: Publications of Institute for Humanities Research and Development.

Abdul, B. M. H. (1993). Seyed Qutb, Hayateh and Adabeh, Egypt: Daraolvafa.

\section{$(\mathrm{cc}) \overline{\mathrm{EY}}$}

This work is licensed under a Creative Commons Attribution 3.0 License. 